\title{
Memory Troubles: Remembering the Occupation in Simone de Beauvoir's Les Mandarins
}

\section{Citation}

Suleiman, Susan Rubin. 2010. Memory troubles: remembering the occupation in Simone de Beauvoir's Les Mandarins. French Politics, Culture and Society 28(2): 4-17.

\section{Published Version}

doi:10.3167/fpcs.2010.280202

\section{Permanent link}

http://nrs.harvard.edu/urn-3:HUL.InstRepos:4817409

\section{Terms of Use}

This article was downloaded from Harvard University's DASH repository, and is made available under the terms and conditions applicable to Open Access Policy Articles, as set forth at http:// nrs.harvard.edu/urn-3:HUL.InstRepos:dash.current.terms-of-use\#OAP

\section{Share Your Story}

The Harvard community has made this article openly available.

Please share how this access benefits you. Submit a story.

Accessibility 


\section{Susan Rubin Suleiman}

\section{Memory Troubles: Remembering the Occupation in Simone de Beauvoir's Les Mandarins}

It is a truth universally acknowledged (to quote Jane Austen wildly out of context) that Simone de Beauvoir's novel Les Mandarins, which won the Prix Goncourt in 1954, is an important work of historical fiction, chronicling the lives and loves of left-wing intellectuals in Paris during the years following World War II. While critics have disagreed about its literary or stylistic merits (as well as about its morality: the Catholic Church placed it on the Index in 1956, along with The Second Sex--and with Françoise Saga's Bonjour Tristesse), no one contests the fact that Les Mandarins chronicles the postwar dilemmas of French intellectuals who considered themselves as independent thinkers - free of submission to any political party or ideology, and also free of any taint of collaboration with the Vichy regime. For many such intellectuals, among whom Sartre and Beauvoir counted themselves, along with Camus and others, the postwar years turned out to be years of disenchantment; as the Cold War took hold, they were faced with an impossible choice between the U.S. and the USSR in international politics and, on the home front, with an impossible choice between Gaullism and communism. The attempt by Sartre and David Rousset, in the late 1940's, to start a "third way" revolutionary movement (the Rassemblement Démocratique Révolutionnaire) that would be independent of the French Communist Party soon foundered; and as far as international politics was concerned, French intellectuals had to face the fact that France had become, at best, a supporting player far overshadowed by the two giants on the world stage. As 
many critics have pointed out, Les Mandarins ends with all of its main characters close to despair; while not quite as hopeless as Beckett's Unnammable, who concludes "I can't go on, you must go on, I'll go on," the heroes of Les Mandarins too decide merely to "go on." "Who knows? Maybe one day I'll be happy again. Who knows?" These words by Anne Dubreuilh, the last line of the novel, pretty much sum up their attitude.

A novel of the postwar, then, oriented toward the future (which of course would be the author's and her contemporary readers' present, give or take a few years), no matter how bleak or uncertain that future might be: that is one possible description of Les Mandarins, and it is a good one. In this essay I would like to explore a different possibility: namely, that Les Mandarins is as much about the war as about the postwar, and as much about the past as about the future. More exactly, I want to argue that it is a novel about memory of the war and the Occupation, and that its meaning for contemporary readers was deeply linked (even if not in a fully recognized way) to that most troubled period in recent French history. Oddly enough, it is from our own contemporary perspective, so heavily informed by concerns over memory and World War II, that this aspect of the novel comes to the fore.

To be sure, readers in 1954 were not unaware of questions about memory and the Occupation. The postwar purge trials of collaborators were nothing if not displays of memory, as well attempts to bring those considered responsible for France's shame to justice. The shame consisted in the fact that France was the only Western European country to have officially collaborated with the Nazis; the Vichy regime sought "full partnership" with the Germans in running the country. But concurrently with the trials of collaborators, which took place between 1945 and 1949, there was also a campaign for 
amnesty —in other words, for a collective forgetting. Amnesty, both in its long history originating in Greece and as it has been practiced in the French republic ever since the late nineteenth century, is an official "wiping clean" of the slate of memories concerning wrongdoing. Voted by the National Assembly, l'amnistie républicaine is by definition a political act whose declared purpose is to bring about national reconciliation after bitter conflicts: the Commune, the Dreyfus Affair, the Vichy years, the Algerian war. ${ }^{1}$ After World War II, most of those who campaigned for amnesty for collaborators came from the political right, as one might surmise, while the Communist Party was staunchly against it; however, a number of former non-communist résistants, such as Jean Paulhan, also argued against further trials of those who had "erred." ${ }^{2}$ A first amnesty (for minor crimes such as blackmarketeering) was voted as early as 1947, freeing more than half of all those who were in prison for collaboration; in 1951 and 1953, two sweeping amnesties emptied the prisons of all but a few of the most serious offenders, and restored thousands of people who had been condemned to "national indignity" to full civil rights.

By 1954, when Les Mandarins was published, France had entered into what the historian Henry Rousso has called the "period of repression" as far as memories of the Occupation were concerned. ${ }^{3}$ One negative effect of the amnesties, Rousso has argued, was to prevent a full airing of the history of that period - and to make the "return of the repressed" of the early 1970 's, when the floodgates of memory opened on every side, all the more of a shock; a shock from which France has still not fully recovered. It is worth emphasizing that the aspect of the Occupation that was repressed more than any of the others, in the 1950's and 1960's, concerned the role of the Vichy government in the persecution of Jews. In the immediate postwar trials, the main accusation of "intelligence 
with the enemy" left little room to dwell on Vichy antisemitism; the focus was on treason, not on crimes against humanity, a concept that was being elaborated during those years at Nuremberg. Interestingly, the persecution of Jews by Vichy was mentioned by some novelists in the immediate postwar years, in particular by writers close to the Communist Party, which prided itself on its Resistance credentials. ${ }^{4}$ Beauvoir herself describes a scene of roundup of Jews in Paris (presumably in July 1942) in her 1945 novel Le sang des autres, not one of her best-known works. By the mid-1950's, however, such memories had faded from public discourse.

And what about Les Mandarins? As I will try to show, Beauvoir's novel is haunted by ambivalent memories of Jewish persecution. It is also concerned with another troubled area, regarding the Resistance, and with general issues of memory and its inevitable obverse, forgetting. How much influence should an awareness of the past have on the present, and on one's projects for the future? This is a question that Beauvoir's characters struggle with from one end of the novel to the other, just as it was a question that she treated in some of her philosophical and autobiographical works.

\section{Falsifying memory and the ethics of ambiguity}

One of the best known episodes in the novel concerns Henri Perron, the writer, newspaper editor and former Resistance hero whose story and inner life we follow throughout the novel (the other center of consciousness is Anne Dubreuilh, a psychoanalyst whose first-person narrative alternates with the chapters concerning Henri). Having written a highly successful play--whose main character, not by chance, is a woman after the war, coming to terms with the murder of her husband by the Nazis-- 
Henri becomes amourously involved with the beautiful young actress Josette Belhomme, who stars in the play. Josette is totally dominated by her mother Lucie, the head of a fashion house who was quite compromised by her relations with German officers during the war but who is now doing just fine; it turns out, however, that Josette too was very compromised, since her first great love was a "handsome but dumb" German captain who was later killed on the Eastern front. Henri is unaware of these facts about the two women. Lucie has been paying blackmail money to a former collaborator and agent for the Gestapo, Mercier, who owns revelatory photographs and documents about her and her daughter. But now she is in trouble, because Mercier has been arrested and he threatens to tell all unless she gets him freed. Mercier had denounced two women résistantes to the Gestapo in 1943, who were deported to Dachau as a result; they have returned, and have identified him in sworn statements. Lucie, summoning Henri to her sumptuous apartment, informs him of all this and tells him that he alone can help—otherwise, if Mercier reveals their past, Josette is sure to commit suicide rather than face public humiliation. Lucie explains to Henri that the only way to get Mercier out of trouble is to claim that he was a double agent, working for the Resistance and pretending to work for the Gestapo; and the only person who can credibly make such a claim is a Resistance hero, Henri himself.

What to do? Henri feels tormented, but not for very long: weighing in the balance Josette's distress and threatened suicide against his "scruples of conscience, ${ }^{5}$ he decides to give false testimony. In the judge's chambers, facing the two deportees who revere him, he smoothly insists that Mercier was with him, far from Paris, on the day the women were arrested. Their clear memory of having been pointed out to the two Germans who 
arrested them by the accused Mercier is thus suddenly made murky. "Elles étaient aussi sûres de l'identité de Mercier que de la loyauté d'Henri et il y avait de la panique dans leurs yeux" ("They were as sure of Mercier's identity as of Henri's loyalty, and there was panic in their eyes"), the narrator writes. In the end, the two women withdraw their testimony and Mercier goes free. The narrator remarks: "Pour ne pas soupçonner Henri, elles consentaient à douter de leur souvenir le plus sûr; mais avec le passé, le présent vacillait autour d'elles, et la réalité même; Henri eut horreur de cette perplexité égarée au fond de leurs yeux" (II, 323; "In order not to suspect Henri, they agreed to doubt their surest memory; but along with the past, the present trembled around them, as did reality itself; Henri was horrified by that wild perplexity in their eyes").

Henri's decision to perjure himself - that is, to create a false memory of the past and thus to negate the past as it actually occurred — is not condemnable, according to the ethics developed in Beauvoir's philosophical essay of 1947, Pour une morale de l'ambiguité. In that work she rejects any ethics based on absolute principles, other than the principle of individual freedom and choice. In the absence of general rules, each moral choice must be considered in its specific circumstances, and only the person who makes the choice can determine its appropriateness. ${ }^{6}$ In one passage, Beauvoir specifically discusses the significance of the past in relation to the present and to future projects, and concludes that there should be no "cult" of the past; if, in a given situation, the past must be "destroyed" in order to save the future, then so be it: "this destruction is a sacrifice" (sacrifice of what? Of the truth, perhaps), but she concludes that a genuine ethics does not bid one to refuse such a sacrifice; instead, "one must assume it" (p. 137). We could say that Henri "assumes"—-that is, takes responsibility for-his own 
destruction of the past, which he accomplishes for the sake of the present well-being of a woman he pities. To his credit, or in any case interestingly, after saving Josette, he breaks off his relationship with her. He also "confesses" what he did to the older philosopher Dubreuilh, who functions as a kind of moral compass in the novel.

Dubreuilh does not condemn him: "In a curved space, one cannot draw a straight line," says Dubreuilh. "You cannot lead a correct life in a society that is not correct" (II, 343).

So from Henri's point of view (and, evidently, from Beauvoir's and the novel's point of view as well), his falsified memory makes sense: while he is not proud of it, he is willing to own it, and the reader is invited to go along with that. What the novel hints is more difficult to accept, however, is the effect of his false testimony on the two women who feel "reality itself" vacillating as they begin to doubt their surest memory on the basis of his words. It's probably a good thing, for Henri as for the reader, that the novel doesn't follow the two résistantes out of the judge's chambers to explore the consequences of Henri's lie on their lives. And this, of course, is a problem in Beauvoir's theory of ethical ambiguity as a whole: if I alone am to determine, freely, the moral value of my actions, what do I do about the consequences of my actions for others? The problem is not one of solipsism: Henri can claim to have sacrificed the truth not for himself but for the sake of a young, vulnerable woman whom he has loved; but aside from being "horrified" when he looks into the two résistantes' eyes, neither he nor the novel inquires about the sequel as far as their lives are concerned. I suppose Beauvoir would say that since you cannot care for everyone, you might as well care for those you are linked to in a personal way. 
The fact that Henri's ethical crisis involves precisely the Resistance is not without historical relevance. By 1954, when the novel was published, the Resistance had become a somewhat undiscussed subject--not taboo, just not talked about much. Right after the war, it was glorified by many: as has often been pointed out, De Gaulle was instrumental in creating a "mythe résistancialiste," according to which all of France had "resisted" the Occupant (Rousso, p. 30). While the critique of the "mythe résistancialiste" would become generalized among historians starting in the 1970's, in the immediate postwar years it was former supporters of Vichy and right-wing and extreme right-wing intellectuals who attacked what they called the "mythe résistantialiste" (with a $t$ ). ${ }^{7}$ Their purpose, unlike that of the later historians, was mainly self-justificatory-smearing the Resistance to make themselves look better--at a time when trials of collaborators were still going on (Rousso, p. 43). With the amnesties of the early 1950's, that purpose became moot; it was not until 1964, with the heroization of Jean Moulin, that the Resistance once again took center stage, this time with a Gaullist twist.

The fact that Beauvoir chose to place her male protagonist's ethical dilemma in a Resistance framework, precisely at a time when the subject was no longer much discussed, is therefore worth pondering. Since the action in Les Mandarins occurs during the 1940's, we could see her choice as a matter of realism; but if that is the case, then it's all the more significant that she has a genuine hero of the Resistance commit an act of betrayal. Henri's false testimony does violence to the two women résistantes, and he is aware of it and reproaches himself for it. This is a case where the ethics of ambiguity points to a historical consequence: if even a Resistance hero can betray those who fought on his side, where does that leave the purity of the Resistance? Beauvoir 
does not develop this question, and may not even have been aware of it; from today's perspective, it is an indication of the troubled memories that surrounded France's role in the war.

\section{'Why did they leave us?' Ambivalent memory and Jewish persecution}

As I said earlier, regarding troubled memories, none were more troubled during the period of "repression" in France than those concerning Jewish persecution during the Occupation. Les Mandarins is haunted by them. While there is not a single Jewish character among the many French people we see living in postwar Paris in this novel, there are plenty of remembrances of Jewish victims who have disappeared. Anne Dubreuilh's daughter Nadine has never totally gotten over the death of her first love, Diégo, who was Jewish; the young journalist and former résistant Lambert still mourns his Jewish fiancée Rosa,who may have been denounced to the Gestapo by his own father; and the former résistant Sézenac, who turns into a bad apple because of his drug habit, is revealed at the end as having "sold" hundreds of Jews to the Germans instead of taking them to safety as he had claimed to do (Sézenac is another character, incidentally, who casts a less than positive light on the Resistance).

It is wholly to Beauvoir's credit that she included these significant mentions of Jewish persecution in the novel, at a time when almost nobody talked about it. (I refer to the persecution of Jews in France, not the Holocaust generally; however, people didn't talk much about the Holocaust either, in 1954, and the word itself did not come into use until the 1960 's). In fact, so deep was the silence on this subject that none of the 
contemporary reviews of Les Mandarins appear to have mentioned its presence in the novel! While I cannot claim to have read all of the more than one hundred reviews, and quite lengthy ones at that, that appeared in the French press in 1954, I have read a good sampling - and the fascinating thing is that none of them mentions the Jews. ${ }^{8}$ Indeed, reviewers seem to have gone out of their way not to talk about them. No reviewer mentions Sézenac's betrayal of the Jews he was supposedly helping, even though its later discovery by Nadine and the others constitutes a fairly important element in the plot; almost nobody mentions Lambert's fiancée, even though her fate is referred to several times in the book. What is truly astonishing, however, from today's perspective, are the omissions concerning Nadine's young lover Diégo, whose death plays an important role in Nadine's behavior and psychology — and she is one of the main characters in the novel. Many reviewers mention Diégo, but they all omit the fact that he was Jewish, and that he died as a Jew. Dominique Aury, writing in La Nouvelle Revue Française, speaks of Nadine's "fiancé," but merely says that "the Germans killed him" ${ }^{9}$; the reviewer in Esprit refers to "the horrifying death of her first lover," but does not elaborate ${ }^{10}$; in Les Nouvelles Littéraires, we read that "Nadine lost her first lover, a new Rimbaud, killed at 17 - no indication of who killed him, or why ${ }^{11} ;$ Le Monde doesn't mention Diégo at all. ${ }^{12}$ As for the Communist press, L'Humanité tells us that "the war killed her young lover," while Les Lettres Françaises explains that he was "shot by the Germans." ${ }^{13}$ How and why was he shot? We are not told.

By contrast, no one can accuse Beauvoir herself, or her novel, of forgetting about the persecution of Jews in France under the Occupation. I will try to show, however, that there was considerable ambivalence in her memories. This is not a reproach, for it can be 
argued that Beauvoir was ahead of her time simply by bringing up the subject when and as she did. But it is an indication of how difficult it was for French people, even those who prided themselves on their anti-antisemitism, to come to terms with what exactly had occurred and what they themselves knew, or remembered, about the Jews in their midst during the war years. (Sartre, whose Réflexions sur la question juive, published in 1946, earned him enormous gratitude among French Jews, made only one mention there of Jews in France under the Occupation, referring briefly to the wearing of the Jewish star).

To demonstrate these ambivalent memories requires close reading; a good place to start is the passage where Diégo is first mentioned, in the second half of chapter one. This placement is quite important, for it is the first time we hear Anne Dubreuilh's voice as narrator-after this, the novel will proceed in alternating chapters devoted to Henri (told by a third-person narrator) and to Anne (narrated by her). ${ }^{14}$ We are in December 1944, and Anne lies awake in her bed after the joyous party celebrating the "first Christmas of peace." Somewhat unusually after such a happy occasion, her first thoughts are about dying, and her first word is No: "Non, ce n'est pas aujourd'hui que je connaîtrai ma mort" "No, it is not today that I will know my death..." (I, 38). Commenting on the two protagonists of Les Mandarins in her memoirs, Beauvoir wrote that she associated Anne with negativity, shame, and fear of death, while Henri represented pleasure, energy and joie de vivre ${ }^{15}$; the mournful opening of Anne's narrative seems to bear that judgment out. As she thinks back on the party, Anne's thoughts slide from the joy of those present to all those who were not there: "le premier Noël de paix; le dernier Noël de Buchenwald,... le premier Noël que Diégo n'a pas vécu" (I, 40; "the first Christmas of peace; the last Christmas at Buchenwald,... the first Christmas that Diégo didn't live to 
see"). And not only Diégo is absent, but many others: Sonia, Rachel, Rosa, all gone forever, all unburied (these are Anne's thoughts). Anne remembers Diégo and Nadine in their happiness: two teenagers, very much in love. Diégo, a former student of Dubreuilh's whose "father was a Spanish Jew" and a wealthy businessman (nothing is said about his mother), spent most of his time at their house, inseparable from Nadine; already a brilliant poet, the boy was full of life and plans. And then there follows, over several pages, the narrative of what happened to him (I, 41-44). One morning, when by chance he had slept at his father's house, the Germans rang the doorbell and took them away. The father's blonde "Aryan" mistress bribed a German named Félix, who promised to help them escape. Meanwhile, Anne and Nadine rode to Drancy on their bicycles, and caught glimpses of them in the tall towers through their 'lorgnettes'. Then, one day, they found the "barracks" ("casernes") deserted, all the rooms empty; some people in a café told them that three "armored trains" ("trains blindés") had left the station during the night. But they saw two people waving to them from one of the empty rooms up high, and were happy: Félix had not lied to them. Later, Félix told the blonde that they had been sent to a camp for "American prisoners," and later still that they had been transferred to other camps; but when Nadine demanded proof that Diego was still alive, Félix turned nasty: "Il y a longtemps qu'on les a abattus" (I, 44: "They were shot a long time ago").

This whole passage is fascinating, both for what Anne remembers and what she seems to be unaware of or misremembers - and for the fact that Beauvoir the novelist even mentions the word "Drancy" as a place where Jews were imprisoned. While Drancy, a northern suburb of Paris, is now emblazoned in many people's minds as the 
name of a detention camp that functioned as an antechamber to Auschwitz, it was certainly not often pronounced in the 1950's, whether by novelists or by historians, in discussions of the Occupation years. Anne, in her narrative, is recalling these events in December 1944. Since she tells us that Diego was still alive the previous Christmas, and that her bicycle rides to Drancy occurred in the spring, the events must have occurred earlier in the same year, 1944; the last visit, when she and Nadine find the camp empty, is explicitly dated as May. All this, of course, was before the French public had any concrete knowledge of the Nazi death camps. ${ }^{16}$ Yet, it seems odd that Anne would not know anything about the deportation of Jews from Drancy, which had been going on since the spring of 1942. She never uses the word "deportation" to refer to Jews in her narrative (either now or later), and it seems as if the information about the "armored trains leaving the station" comes as news to her. (The information is itself erroneous, for the Jews deported from Drancy left in buses that took them to Le Bourget, and from there they were transferred to sealed merchandise wagons, not to armored trains). Above all, it is impossible that Anne could have seen all the buildings at Drancy emptied, for the camp continued to function and be occupied by more than a thousand prisoners until late August 1944; the last deportation train left on August $17 .{ }^{17}$ Anne's memory of that afternoon in May was therefore a false or misremembered memory. This is, to be sure, not obvious to a reader who has not done research on the subject, but once we have done the research, it raises an interesting question: was Anne's ignorance and misremembering shared by Beauvoir herself? And if so, what does that tell us about what I am calling ambivalent memory about Jews during the Occupation? 
As it happens, Beauvoir retold the story of Diégo six years after Les Mandarins, in her memoir La Force de l'Age--this time as "autobiographical fact," not as fiction. The Diégo figure is there named Bourla, "un jeune Juif espagnol" ("a young Spanish Jew") who had been Sartre's student in 1941 at the Lycée Pasteur. Bourla and "Lise" (Beauvoir's former student and sometime lover Natalie Sorokine, who is considered to be the model for Nadine in Les Mandarins) became lovers, sharing a room in the same hotel as Beauvoir. She tells exactly the same story here as in the novel, down to details such as the fact that she would go to "tuck them in" at night and Bourla would ask her to kiss him as well as Lise. ${ }^{18}$ One difference is that in the memoir, the story of Bourla's arrest is not told right after he is first mentioned but occurs fifty pages later, in its chronological place: in the spring of 1943, around the time of the Allied landing in Italy. It is exactly the same story: Bourla arrested with his father, the father's blond girlfriend, the German named Félix who was going to get them out. Beauvoir and Nadine ride out to Drancy on their bikes, are told by people in a café that "armored trains" had left the station during the night, and see the empty camp with their own eyes; the narrative then continues as in the novel, right up to Félix's horrible pronouncement that Bourla and his father were shot a long time ago.

Here then is a case where an autobiography "borrows" textually from a novel, instead of the more usual sequence where a novelist might incorporate into fiction an incident he or she had already noted in an autobiography. But the really significant fact, or rather the problem, is that this time it is Beauvoir herself who misremembers the episode of the empty camp: the fictional Anne's failure of memory has here migrated to her creator, and we can no longer be sure what is remembered and what is invented. 
What we can be sure of is that the incident, as it is recounted both in the novel and in the memoir, is historically inaccurate.

Is it more serious when Beauvoir herself, rather than her character, errs in her memories? Yes, but it is precisely what indicates ambivalent memory: one remembers, but one does not remember accurately, because it would be too painful to do so. A similar ambivalence exists when Beauvoir reports in her memoirs not what she remembers, but what she "knew" during the war about the deportation of the Jews. At several moments in La Force de l'Age, Beauvoir (who does use the word deportation regarding the Jews, unlike Anne) reports that the Jews were "déportés en Allemagne" ("deported to Germany"). In the Bourla episode, she puts this information into the mouth of the German Félix, which makes it suspect ("Félix annonça un matin à la blonde que tous les internés de Drancy venaient d'être expédiés en Allemagne...", p. 591; "Félix announced one morning to the blonde that all the inmates from Drancy had been sent to Germany" - this detail does not appear in the novel). But elsewhere in the memoir, Beauvoir she reports this information on her own authority: "Des milliers de Juifs étrangers furent internés dans un camp, à Pithiviers, et on commença à les déporter en Allemagne" (FA 496; "Thousands of foreign Jews were interned in a camp, in Pithiviers, and they started deporting them to Germany"), or "Des trains de déportés partaient, massivement, vers l'Allemagne" (FA 540; "Trains of deportees were leaving, in large numbers, toward Germany"). If it is possible that this is what Beauvoir and her friends "knew" in 1942 or 1943, it is impossible that the Beauvoir of 1960, who was writing the memoir, did not know better: the deportation trains of Jews, whether from Pithiviers or Drancy, left not for Germany but for Poland; their destination was Auschwitz, or 
occasionally another death camp. ${ }^{19}$ Danièle Sallenave has shown, in her book Castor de guerre, that Beauvoir often does this kind of strategic withholding in her autobiography, leaving uncorrected the mistaken impressions or false knowledge of her younger self. ${ }^{20}$

In this instance, the lack of correction creates a situation of ambivalent memory: we are told what Beauvoir knew, and deplored, about the sad fate of the Jews during the war; but we are not told the whole story. In particular, we are never told that the arrests-and even the deportations--were most often carried out by French police, or by French and Germans together, not just by the Germans; in both the novel and the memoir, it is the Germans who ring the doorbell early in the morning to arrest the boy and his father. Perhaps Beauvoir did not know, in 1960, about the role of the French police in the wartime arrests; or perhaps, ambivalently, it was something she could not allow herself to know or to recall.

To return now to Anne's nighttime soliloquy in the beginning of Les Mandarins, perhaps the most interesting, or one might say symptomatic, passage occurs right after her account of Diégo's arrest and death. How can those who have survived deal with their memories and their remorse over the dead, Anne asks. "Que faire d'un cadavre?" "What should one do with a corpse?" Nadine screamed for several nights after she learned of Diégo's death; but eventually, she stopped screaming, and on this Christmas eve she had danced with Lambert, who had also lost a loved one, his Jewish fiancée Rosa. Waving the flag or constructing monuments is a betrayal of the dead, Anne thinks, but "leaving their ashes in peace" is not much better: in either case, they're no longer with us, whereas once "they had been our brothers." She continues: "Mais nous n'avons pas le choix: pourquoi nous ont-ils quittés? Qu'ils nous laissent en paix eux aussi. 
Oublions-les." (I, 44; "But we have no choice: why did they leave us? Let them leave us in peace too. Let us forget them").

The only way to go on living, it seems, without dying of remorse at having survived, is to turn the blame onto the dead themselves: Why did they leave us? What this question elides is the fact that people like Diégo and Rosa, and so many thousands of others, did not "leave" their loved ones - they were forcibly torn from them. The defense mechanism of projection, whereby one projects onto others the fault one blames in oneself, is here beautifully illustrated. In such projection, the difference between subject and object, between active agent and passive victim, becomes blurred, or reversed. Why did they leave us? We are not responsible for their leaving; let us forget them. It is all the more interesting that Anne is the person saying this, for she is a psychoanalyst by profession and presumably recognizes projection for what it is: an attempt by the psyche to protect itself from a crippling sense of guilt or shame. In fact, she returns to the question of forgetting at several other moments in the novel, notably when she is treating patients who have undergone trauma during the war. While she realizes that to help them go on with their lives she has to help them forget, she feels quite ambivalent on that score. And much later, at the very end of the novel (1948 in fictional time), she confronts the question once again, again in relation to the death of Jews in France. Trying to dissuade Nadine, who wants to make the addict Sézenac "pay" for all the Jews he betrayed, Anne tells her: "What good would it do to make him pay? We cannot ressuscite the dead." Nadine retorts, "But we cannot forget them," to which Anne replies "We have forgotten them" (II, 467-8). Life has gone on. 
What to remember and what to tell? How to integrate the memory of the war into the present, without letting it paralyze us? That is the question Anne and those around her (but especially Anne) confront repeatedly in Les Mandarins; and it was also the question that Beauvoir herself attempted to struggle with in her postwar writings. In $L a$ Force des choses, she recalls that soon after the Liberation, the newspapers started to give details on "the massacres, the executions of hostages, the destruction of Warsaw. ...That past, brutally revealed [dévoilé], threw me into horror; the joy of living gave way to the shame of having survived" $(F C, 21)$. Twenty pages later, when she tells about her discovery of the Nazi camps in 1945, Beauvoir writes: "Once again, I was ashamed of being alive" $(F C, 45)$. Between these two passages of shame and guilt, however, she details how interesting life was becoming for her and Sartre, after the war: the trips they took, the new people they met, the books they published, the plays they saw. In her later comments on Les Mandarins, she assigns joie de vivre to the male writer, and shame and guilt to the female psychoanalyst. But she also tells us that she herself identified with both of those characters. Perhaps what I have been calling her ambivalent memories of the Occupation are another version of that split.

Finally, it is not surprising that the ambivalence of those memories manifests itself most strongly in relation to the Jews. Hélène Berr, a young assimilated Jewish woman who kept her journal in Paris from 1942 until close to the day she and her parents were arrested by French police, early in the morning of March 3, 1944, remarks more than once how difficult she finds it to look at people on the street and in the métro as she walks among them with her yellow star, and to realize that they don't really comprehend, and don't want to comprehend, what is happening to the Jews. One non-Jewish 
acquaintance asks her, in October 1943, when she has already seen many of her friends deported, whether she "misses being able to go out at night" (because of the laws forbidding Jews to frequent theaters and restaurants). "My God," she writes, "he thinks we are still at that stage!"121 And a month later, when a neighbor expresses shock and outrage upon hearing that a young Jewish woman and her two babies have been taken to Drancy, Hélène notes somewhat bitterly that "finally she understood, because it happened to someone she knew." She then continues: "Not to know, not to understand, even when one knows, because a door remains closed in you, the door which, when it finally opens, allows you to realize the part you simply knew. That is the immense drama of these times. No one knows anything about the people who are suffering." (Journal, 219-220). We could similarly say that for many years after the war, no one wanted to remember exactly how things went with the Jews at Drancy, and elsewhere in France. But we should recall as well that "only" about $25 \%$ of the Jews of France were murdered during the war, while the rate was much higher in other European countries from which Jews were deported. Many non-Jewish Frenchmen and women went out of their way to help Jews, at danger to themselves and their families.

Beauvoir was not among those "righteous Gentiles," but she did remember Drancy, in her writings, at a time when few others did; and she also expressed remorse and shame at the suffering of others during the war, especially Jews. The fact that she did so with some ambivalence, alternating between horror and joie de vivre, shows that she was human.

\section{NOTES}


${ }^{1}$ For a useful history of amnesty in France, see Stéphane Gacon, L'Amnistie; De la Commune à la guerre d'Algérie. Paris: Seuil, 2002. I discuss some of the theoretical issues involving the postwar amnesties in my book Crises of Memory and the Second World War (Cambridge, MA: Harvard U.P., 2006), chap. 9: "Amnesia and Amnesty: Reflections on Forgetting and Forgiving."

${ }^{2}$ Paulhan's Lettre aux Directeurs de la Résistance, first published in 1952, addresses exactly this question, and provoked a lively public debate among former résistants.

${ }^{3}$ Rousso, Le syndrome de Vichy, 2e éd. (Paris: Seuil, 1990), chap. 2: "Le refoulement."

${ }^{4}$ Elsa Triolet mentions Jewish persecution by Vichy in Le premier accroc coûte deux cents francs, her collection of stories (some of them published clandestinely during the war) which won the Prix Goncourt in 1945. Vercors (Jean Bruller) mentions the Vichy "Jewish decrees" and subsequent roundups of Jews in his 1945 novella, "L'imprimerie de Verdun." During the war, in 1943, Vercors had published "La marche à l'étoile," another novella emphasizing Jewish persecution, at the Editions de Minuit. Both Triolet and Vercors were themselves Jewish. I wish to thank Margaret Atack and other participants in the "Framing Narratives" conference at the University of Leeds (September 2009) for bringing "L'Imprimerie de Verdun" to my attention.

${ }^{5}$ Beauvoir, Les Mandarins (Paris: Gallimard, 1954, Folio ed.), vol, II, p. 320; subsequent references to this edition will be given parenthetically in the text, by volume and page number. All translations from the French are my own.

${ }^{6}$ Beauvoir, Pour une morale de l'ambiguité (Paris: Gallimard, 1947, "Idées"), p. 220; subsequent page references will be given parenthetically.

${ }^{7}$ Marcel Aymé's 1948 novel Uranus is a good example of such early "demythifications" of the Resistance. Aymé, while not a collaborator, was quite sympathetic to the Vichy regime and in the novel he paints a very negative picture of both real and would-be résistants.

${ }^{8}$ For an exhaustive account of the novel's critical reception (which does not deal with any aspect of the subject I am discussing here) and a complete list of reviews, see Björn Larsson, La Réception des Mandarins: Les roman de Simone de Beauvoir face à la critique littéraire en France. Etudes Romanes de Lund, 41 (Lund: Lund University Press, 1988).

${ }^{9}$ D. Aury, "Personne ne triche," Nouvelle Revue Française, December 1954, p. 1082.

${ }^{10}$ Simone Fraisse, "Journal d'une femme de quarante ans," Esprit, March 1955, p. 487.

${ }^{11}$ Robert Kemp, "Les Mandarins," Les Nouvelles Littéraires, 28 Oct. 1954, p. FILL IN

${ }^{12}$ Emile Henriot, "Les Mandarins," Le Monde, 10 Nov. 1954, p. 9.

${ }^{13}$ Hélène Parmelin, "Les Mandarins," L'Humanité, 7 Dec. 1954, p. FILL IN; Anne Villelaue, "Simone de Beauvoir nous donne avec 'Les Mandarins' un roman politique de 1944 à 1947, Les Lettres Françaises, 21 Oct. 1954, p. 1 and p. 4.

${ }^{14}$ I have discussed some implications of this split narrative in my book Risking Who One Is: Encounters with Contemporary Art and Literature (Cambridge, MA: Harvard U.P., 1994), chap. 4: "Simone de Beauvoir and the Writing Self."

${ }^{15}$ Beauvoir, Les Force des choses (Paris: Gallimard, 19--), p. 288. Hereafter, cited parenthetically as $F C$.

${ }^{16}$ Historians have puzzled over the question of "Who knew what, when?" regarding the exact fate of deported Jews. In France, radio broadcasts from the BBC as early as July 
1942 mentioned gas chambers and systematic extermination of Jews; as Denis Peschanski notes, however, even though many French people listened to the BBC, "the fact that the message was listened to does not mean that it was heard" (see Peschanski, "Que savaient les Français?" in Qui savait quoi? L'extermination des Juifs 1941-1945, ed. Stéphane Courtois and Adam Rayski (Paris: La Découverte, 1987), p. 87.

${ }^{17}$ For the historical information cited about Drancy, see André Kaspi, Les Français pendant l'Occupation, éd. revue et mise à jour (Paris: Seuil, 1997), p. 276 and p. 273.

${ }^{18}$ Beauvoir, La Force de l'âge (Paris: Gallimard, 1960), p. 543. Hereafter, cited parenthetically as $F A$.

${ }^{19}$ In the second quote above, Beauvoir writes "toward" Germany, which could mean simply, toward the east. But if so, that is still a euphemism that refuses to acknowledge that the destination was not Germany.

${ }^{20}$ D. Sallenave, Castor de guerre (Paris: Gallimard, 2008), p.FILL IN

${ }^{21}$ Hélène Berr, Journal (Paris: Tallandier, 2008), p. 178. 